\title{
The Making of a Biochemist I: Frederick Gowland Hopkins' Construction of Dynamic Biochemistry
}

\author{
HARMKE KAMMINGA and MARK W WEATHERALL*
}

In this two-part study, we present a new perspective on the activities of British biochemist Frederick Gowland Hopkins (1861-1947). The title shared by the two papers - 'The Making of a Biochemist' - refers first of all to Hopkins' career and his articulation of a dynamic approach to biochemistry, which Hopkins promoted actively for over twenty-five years. This is the subject of our first paper. The title also refers to the construction of a view of Hopkins by others, including his peers, his younger colleagues, and historians of biochemistry. These constructions, and the extent to which they do and do not accord with Hopkins' own endeavours and intentions, form the subject matter of our second paper, which will appear in the October issue.

Historians have thus far focused primarily on Hopkins' role as a discipline builder and on the wide-ranging programme of research and teaching in biochemistry that he set up in Cambridge in the interwar period. ${ }^{1}$ This programme, characterized by its separation from medical concerns and its broad biological scope, has been viewed as the practical expression of Hopkins' prior "vision" of biochemistry. ${ }^{2}$ Here we examine related issues that have not yet received the attention they deserve, namely the relationships between Hopkins' own research and his particular view of biochemistry, and the detailed construction of Hopkins' "dynamic biochemistry" over time.

To this end, we follow Hopkins himself, through the laboratory and through the public domain, examining his public pronouncements on the nature and needs of biochemistry and pointing to prominent themes in Hopkins' own research which, we argue, informed his vision of dynamic biochemistry. We outline how that vision then shaped the research done in Hopkins' department, and how, in turn, that research collectively gave new

\section{"Harmke Kamminga, $\mathrm{PhD}$, and Mark W Weatherall, $\mathrm{PhD}$, Wellcome Unit for the History of Medicine, Department of History and Philosophy of Science, University of Cambridge, Free School Lane, Cambridge CB2 3RH, UK.}

We thank Richard Summers and Dr Christopher Thorne of the Department of Biochemistry, Cambridge, for generously providing photographs of the wood carvings in the Department's Colman Library.

1 R E Kohler, From medical chemistry to biochemistry: the making of a biomedical discipline, Cambridge University Press, 1982; M Teich with

\author{
D M Needham, A documentary history of \\ biochemistry, 1770-1940, Leicester University Press, \\ 1992, pp. 510-20; and accounts by Hopkins' \\ colleagues in J Needham and E Baldwin (eds), \\ Hopkins \& biochemistry, 1861-1947, Cambridge, \\ Heffer, 1949. On Hopkins' school, see further \\ M Weatherall and H Kamminga, Dynamic science: \\ biochemistry in Cambridge, 1898-1949, Cambridge \\ Wellcome Unit Publications, 1992. \\ 2 Especially Kohler (op. cit., note 1 above) \\ presents Hopkins' "vision" of biochemistry as being \\ unconnected to his own research, and suggests that \\ this vision was subsequently translated into a \\ research programme of "general biochemistry", \\ largely through the efforts of Hopkins' colleagues.
}




\section{Harmke Kamminga and Mark W Weatherall}

substance to Hopkins' vision over the years, in a series of reciprocal reinforcements. In other words, we present Hopkins' construction of dynamic biochemistry as a long-term process, in which new directions of research and new rhetorical emphases were interlinked.

We also draw attention to Hopkins' formulation of a past tradition, in which he mapped out a path towards his own novel style of dynamic biochemistry, and we suggest that his presentation of that past tradition should be seen as part of his endeavours to create a future for his dynamic biochemistry. Our account is the first to demonstrate the coherence between the scientific, the rhetorical and the historical dimensions in Hopkins' construction of dynamic biochemistry. We consider how that coherence was maintained and consolidated over time, especially by the ways in which Hopkins stressed issues of unification in his presentations of dynamic biochemistry as the fundamental science of life.

Hopkins continued to promote his unifying, dynamic biochemistry persistently, long after he had acquired a secure institutional footing. In our companion paper, we explore the question why this central feature of Hopkins' endeavours has, to date, received so little attention in the history of biochemistry. We approach that question by examining reputations ascribed to Hopkins by others in his circle, and by considering the ways in which these reputations have been adopted by historians. The two papers together offer a substantial revision of the views of Hopkins that have been disseminated among biochemists and among historians.

\section{Hopkins' Biochemistry in the Making}

Through most of his career, Hopkins was in demand as a public lecturer, and his addresses provide important insights into his efforts to promote biochemistry as a fundamental science of life. In looking at Hopkins' public addresses systematically, we have been able to identify recurring themes as well as shifts in content or emphasis, bearing in mind also the phase of Hopkins' career during which particular lectures were given, the nature of the occasions on which they were delivered, and the kind of audiences to which they were addressed. ${ }^{3}$

Hopkins' earliest surviving public statement of his aims for biochemistry is the renowned address, 'The dynamic side of biochemistry', which he delivered, as Section President, to the Physiological Section of the British Association for the Advancement of Science at its 1913 meeting in Birmingham. ${ }^{4}$ Before then, Hopkins' public lectures to

\footnotetext{
3 We have examined all extant texts of Hopkins' public lectures (over 50 in number), dating from 1900 to 1938 . Most of them were published shortly after they were delivered. Of the 15 addresses included in Needham and Baldwin, op. cit., note 1 above, three had not been published previously. Hopkins' texts of a further six unpublished lectures are held in the Wellcome Unit for the History of Medicine, Cambridge.

4 F G Hopkins, 'The dynamic side of biochemistry', Report of the proceedings of the $B A A S, 1913$, pp. 652-68. (Our page references are to
}

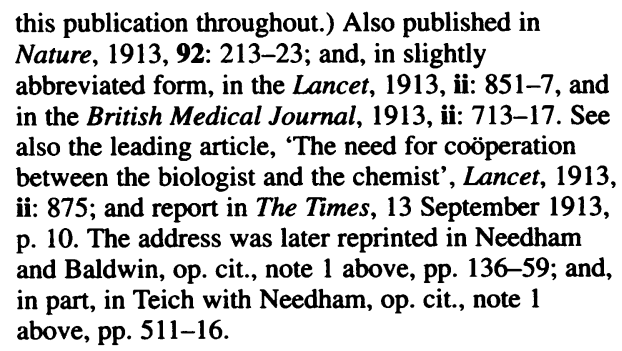
in the British Medical Journal, 1913, ii: 713-17. See also the leading article, 'The need for coöperation between the biologist and the chemist', Lancet, 1913, ii: 875; and report in The Times, 13 September 1913, p. 10. The address was later reprinted in Needham and Baldwin, op. cit., note 1 above, pp. 136-59; and, in part, in Teich with Needham, op. cit., note 1 above, pp. 511-16. 


\section{The Making of a Biochemist}

scientists and physicians invariably stressed the importance of chemical research for medical science, regardless of his precise subject matter or his audience. At that stage, Hopkins was concerned above all with raising the profile of the chemist's contributions to physiology and pathology. The 1913 address, by contrast, signifies a radical break. ${ }^{5}$ Here medical matters were barely touched on. Instead, the lecture amounted to a biochemical "manifesto", presenting an ambitious vision of what biochemistry could and should be, with the explicit aim of inspiring potential recruits.

Hopkins' address to the British Association received very wide publicity in the national, medical and scientific press, and it has come to be regarded as a seminal point in the making of British biochemistry. In re-examining the content of Hopkins' lecture, we focus on its dominant themes of chemical simplicity and chemical dynamics, with a view to examining their relationship to Hopkins' own research of the previous two decades.

\section{The Dynamic Side of Biochemistry}

In his 1913 address, Hopkins presented biochemistry as being centred on the investigation of chemical changes involved in fundamental biological processes: the biochemist does not merely identify substances isolated from the animal, but studies the reactions in which these substances take part in the body, and the ways in which these reactions are controlled and coordinated. This is what Hopkins called the dynamic side of biochemistry. He offered a view of the living cell as an organized, chemically dynamic unit in which simple, chemically identifiable molecules undergo reactions that are open to chemical investigation. Insight into the chemical dynamics of intermediary metabolism would, Hopkins promised, yield novel biological understanding. To further this end, Hopkins issued a clarion call to young chemists in Britain, urging them to help forge the combination of chemistry with biology, and hailing the exciting progress that was beginning to be made in that direction in continental Europe and America.

Early on in his lecture, Hopkins stated clearly what biochemistry involves:

My main thesis will be that in the study of the intermediate processes of metabolism we have to deal not with complex substances which elude ordinary chemical methods, but with simple substances undergoing comprehensible reactions.... I intend also to emphasise the fact that it is not alone with the separation and identification of products from the animal that our present studies deal; but with their reactions in the body; with the dynamic side of biochemical phenomena. ${ }^{6}$

Throughout his lecture, Hopkins stressed that biochemistry deals with comparatively simple molecules. The skilled chemist need no longer be deterred from identifying these

\footnotetext{
5 Some caution is in order, however, in view of what may have been a transitional case. In June 1909, Hopkins presented 'Two lectures on biological chemistry' at the Royal Institution in London. While the texts of these lectures have not survived, the programme listed 16 topics for each of them. Many of these topics have physiological and pathological connotations (for example 'Oxygen and the athlete', 'Cretins, dwarfs and giants', and 'Advantage of variety in diet'), while others fall into the category of fundamental biochemistry (for example 'The living
}

cell as a transformer of energy', 'The part played by oxygen in living processes', 'Catalysis by enzymes; their organisation in the living cell'). Although it is impossible to speculate about the tone of these lectures, the programme suggests that Hopkins had begun to bring a range of basic biochemical themes into the public domain before 1913. Only one, somewhat sensational, press report of these lectures appeared; see Westminster Gaz., 2 June 1909, pp. 2 and 13.

6 Hopkins, op. cit., note 4 above, p. 653. 


\section{Harmke Kamminga and Mark W Weatherall}

molecules by the old slogan that "Thierchemie is Schmierchemie", or by mystifying notions of giant molecules or "biogens" of unstable and intractable constitution. At the same time, in the living animal these simple molecules undergo change, and for Hopkins it was these changes that form the proper subject matter of the new biochemistry. By elucidating the nature of all intermediary substances in a chain of reactions, the chemist could make major contributions to our understanding of the dynamics of the living cell.

That pursuit did not merely involve identifying the molecules taking part in intermediary metabolic reactions, but also studying the control of these reactions, notably by enzymes, and their organization within the cell. Far from advocating a crude chemical reductionism, Hopkins viewed the living cell as an organized, highly differentiated system of interdependent processes in dynamic equilibrium:

It is important to remember that changes in any one of these constituent phases . . must affect the equilibrium of the whole cell-system, and because of this necessary equilibrium-relation it is difficult to say that any one of the constitutent phases ... is less essential than any other to the "life" of the cell ... Certain of the phases may be separated, mechanically or otherwise, as when we squeeze out the cell juices, and find that chemical processes still go on in them; but "life", as we instinctively define it, is a property of the cell as a whole, because it depends upon the organisation of processes, upon the equilibrium displayed by the totality of the co-existing phases. ${ }^{7}$

Hopkins thus presented an integrated picture of the chemical dynamics of the living cell, appealing to physicochemical equilibrium dynamics as well as analytic organic chemistry. He further stressed the great variety of specific catalytic phenomena of the cell. Yet he used the resulting complexity as an incentive for chemists to look for an underlying simplicity which, he suggested, remained to be discovered:

The very complexity, therefore, which is apparent in the catalytic phenomena of the cell to my mind indicates that we must have here a case of what Henri Poincaré has called la simplicité cachée. Underlying the extreme complexity we may discover a simplicity which now escapes us. If so, I have of course no idea along what lines we are to reach the discovery of that simplicity, but I am sure the subject should attract the contemplative chemist, and especially him who is interested and versed in the dynamical side of his subject. If he can arrive at any hypothesis sufficiently general to direct research he will have opened a new chapter of organic chemistry-almost will he have created a new chemistry. ${ }^{8}$

The fruits of the promised land that awaited the young chemist in the realm of the living cell, then, were potentially very rich indeed. But the chemist, too, should be prepared to act as an integral part of an organized and differentiated whole: Hopkins characterized the subject of biochemistry as a "borderland" where chemical knowledge must be combined with "trained instinct and feeling for biological possibilities". 9 Hopkins used the "borderland" metaphor several times and stated that it was a moot point whether its workers were best recruited from the biological or the chemical side. At that juncture, however, he felt that the need was greatest for able young students who had acquired

7 Ibid., p. 663.

8 Ibid., p. 666. Henri Poincaré discussed the hidden simplicity underlying apparently complex phenomena that is captured by certain physical laws in his Science and hypothesis, London, Walter Scott
Publishing Co., 1905, ch. 9: 'Hypotheses in physics'. His examples include the kinetic theory of gases and Newton's laws of planetary motion.

9 Ibid., p. 658. 


\section{The Making of a Biochemist}

technical skills in chemistry. He also urged them to subject themselves to another discipline for a year or two:

If he merely migrate to a biological institute, prepared to determine the constitution of new products from the animal and study their reactions in vitro, he will be a very useful and acceptable person, but he will not be a bio-chemist. ${ }^{10}$

For Hopkins, chemistry and biology are unified in the borderland that harbours biochemistry: the chemists and the biologists working in this borderland have different skills to contribute, but, if they are to be biochemists, they must not only share the goal of elucidating the chemical dynamics of biological processes, but be intellectually equipped to appreciate the significance of their joint contributions in the journey towards that goal.

Hopkins' 1913 address was programmatic in tone; yet the dominant themes which he used to stress the importance and promise of investigating cellular metabolism-chemical individuality and simplicity, dynamics and control-express central concerns in Hopkins' own earlier research, as we now aim to show. We shall also pose the question why Hopkins waited until 1913 to bring these concerns into the public domain.

\section{Before the "Manifesto": Hopkins' Early Research in Biochemistry}

Trained both in analytical chemistry and in medicine, Hopkins began his research career in the 1890s in the laboratories of Guy's Hospital in London. Straddling chemical, physiological and pathological concerns, he there built up a solid reputation for his highly skilled chemical analyses of biological substances, his primary concern being the isolation of substances in pure form as "chemical individuals". Hopkins' research on the chemistry of urine, much of it in collaboration with Archibald Garrod, directly inspired his interest, not only in chemical individuality, but in intermediary metabolism: in "metabolism in compartments" as opposed to "metabolism in block", the latter representing the traditional approach of looking at inputs and outputs, and making (often ill-founded) inferences about what happens in between. ${ }^{11}$

Between 1890 and 1898, Hopkins published (alone or in collaboration) a dozen papers on urine analysis, culminating in a major review, 'The chemistry of urine', which he was invited to write for the first volume of E A Schäfer's widely used Text-book of physiology. ${ }^{12}$ In this contribution, Hopkins reviewed contemporary understanding of the subject in relation to its physiological and pathological significance, and indicated directions for future research. The work opens with revealing programmatic statements:

The chemical study of urine gains its chief importance from the light which it throws upon the process of metabolism. It is concerned mainly with a consideration of the nature and amount of the various metabolic end-products, normal or pathological, which converge into and appear together in the highly complex excretion of the kidneys.

\footnotetext{
10 Ibid., p. 667.

11 Hopkins adopted this terminology from Garrod, who became a life-long friend. See A G Bearn, Archibald Garrod and the individuality of man, Oxford, Clarendon, 1993.

12 F G Hopkins, 'The chemistry of urine', in
}

\author{
E A Schäfer, Text-book of physiology, Edinburgh, \\ Young J Pentland, 1898, vol. 1, pp. 570-638. (For \\ more detail on Hopkins' early research and career, \\ see M W Weatherall, 'Scientific medicine and the \\ medical sciences in Cambridge, 1851-1939', \\ $\mathrm{PhD}$ thesis, University of Cambridge, 1994, ch. 4.)
}




\section{Harmke Kamminga and Mark W Weatherall}

The great importance of this point of view has led perhaps to undue neglect of a second aspect of the subject-the consideration of the renal excretion as a complex whole; as a chemical fluid with individual characters of its own; characters which are not to be foretold from a knowledge of the nature and amount of each constituent considered separately, but require for their explanation the further consideration of the mutual effects of the constituents one upon another, as they exist side by side in solution. ${ }^{13}$

Hopkins went on to state that, while the study of metabolic products relied mainly on the techniques of analysis, the study of the urine as a whole relied also on knowledge of conditions of equilibrium in complex solutions: organic analytical chemistry was to be joined by the new physical chemistry of Svante Arrhenius, J H van't Hoff and Walther Nernst, the chemistry that deals with "the distribution of chemical forces in complex mixtures". ${ }^{14}$ While the emphasis in the review was on the chemical composition of each component of the urine, along with its physiological and pathological relations and its chemical derivation, Hopkins here clearly announced his interest both in equilibrium dynamics and in intermediary metabolism.

When, in 1898, Hopkins accepted Michael Foster's invitation to join the Physiological Laboratory in Cambridge as a lecturer in chemical physiology, he continued work begun in London on the chemistry of proteins. His chief aim was to isolate proteins in a state of "chemical individuality", but before long metabolic considerations came to the fore. In 1901, Hopkins and Sydney Cole showed that "tryptophane", until then a substance of obscure chemical identity and physiological function, is an amino acid (which was later renamed tryptophan). ${ }^{15}$ The physiological importance of tryptophan was demonstrated in Edith Willcock's experiments, published jointly with Hopkins, which showed that if mice are fed zein, a protein which does not contain tryptophan, they stop growing normally and soon die. ${ }^{16}$ Addition of tryptophan to the diet prolonged survival significantly, while addition of the amino acid tyrosine had no such effect. The implication that a dietary supply of tryptophan is essential for animal growth and survival suggested that this amino acid (unlike tyrosine, for instance) cannot be produced from precursors in the normal course of animal metabolism. ${ }^{17}$

This outcome provided a link with Hopkins' interests in intermediary metabolism, and motivated a new line of research concerned with the metabolic role of individual amino acids. He began a series of animal feeding experiments, using diets composed of pure ingredients of known chemical constitution and systematically varying the amino acid content of these diets. In the course of these investigations, Hopkins noted that diets of pure protein (even with an adequate amino acid composition), carbohydrate, fat, minerals

13 Ibid., p. 570.

14 Ibid., p. 571. Hopkins referred specifically to Nernst on p. 572.

${ }^{15}$ F G Hopkins and S W Cole, 'A contribution to the chemistry of proteids. Part 1. A preliminary study of a hitherto undescribed product of tryptic digestion', J. Physiol., 1901, 27: 418-28.

16 E G Willcock and F G Hopkins, 'The importance of individual amino-acids in metabolism: observations on the effect of adding tryptophane to a dietary in which zein is the sole nitrogenous constituent', J. Physiol., 1906, 35: 88-102.

\footnotetext{
${ }^{17}$ Further work along these lines by Hopkins and others established that, besides tryptophan, there are other "essential amino acids", as they became known. See, for example, H Ackroyd and F G Hopkins, 'Feeding experiments with deficiencies in the amino-acid supply: arginine and histidine as possible precursors of purines', Biochem. J., 1916, 10: $551-76$. In a lecture delivered in 1916, Hopkins mentioned five amino acids that animals need to be supplied with in the diet. See F G Hopkins, 'Newer standpoints in the study of nutrition', Trans. chem. Soc., 1916, 109: 629-49.
} 


\section{The Making of a Biochemist}

and water fail to support animal growth, leading him to suggest the existence in normal diets of tiny quantities of as yet unidentified substances that are essential for animal growth and survival. He called these hypothetical substances "accessory food factors" and hinted at a possible link between a lack of such nutrients and diseases such as scurvy and rickets. ${ }^{18}$ Hopkins continued his feeding experiments and tried to isolate accessory food factors, with a view to determining their chemical identity and studying their role in animal metabolism. His impressive series of feeding experiments, demonstrating the need for accessory food factors in the "fundamental process of growth", were published in 1912. ${ }^{19}$ After that, Hopkins published very little original scientific work on accessory food factors, or vitamins, as these nutrients were renamed. His failure to isolate any such substances as chemical individuals long remained a source of frustration: as Hopkins reiterated for years in public lectures, without knowledge of the chemical structure of vitamins, no insight could be gained into their specific roles in metabolism. ${ }^{20}$

While much of Hopkins' early work in Cambridge concerned the organic chemistry of proteins and the metabolic role of their amino acid constituents, he also entered the physicochemical realm of chemical dynamics. Around 1905, Hopkins embarked on investigations of chemical changes during muscle action, with his colleague Walter Morley Fletcher. Their joint paper of 1907, on the oxidative control of lactic acid formation during muscle contraction, fatigue and recovery, was presented explicitly as a study in chemical dynamics. ${ }^{21}$ Illustrated with reaction velocity curves under systematically varied conditions, their paper demonstrated rigorously that muscle contraction is accompanied by the anaerobic formation of lactic acid, which is then removed aerobically, at rates depending on the level of exposure to oxygen. Fletcher and Hopkins' careful experiments opened, as Henry Dale put it later, "one of the great chapters of modern biochemistry. It vindicated the claim that metabolism, as a dynamic process, was accessible to study in detail by methods of exact chemistry."22

\footnotetext{
18 F G Hopkins, 'The analyst and the medical man', Analyst, 1906, 31: 385-97 (lecture to the Society of Public Analysts, November 1906).

19 F G Hopkins, 'Feeding experiments illustrating the importance of accessory factors in normal dietaries', J. Physiol., 1912, 44: 425-60.

${ }^{20}$ For example, F G Hopkins, 'Newer aspects of the nutrition problem', New York, Columbia Press, 1922 (Chandler Lecture, Columbia University, 1921), pp. 14-18; and F G Hopkins, 'Discussion on vitamin-A and the carotenoids', in Chemistry at the centenary meeting of the British Association, Cambridge, Heffer, 1932, pp. 79-81.

21 W M Fletcher and F G Hopkins, 'Lactic acid in amphibian muscle', J. Physiol., 1907, 35: 247-308.

22 H H Dale, 'Frederick Gowland Hopkins, 1861-1947', Obituary notices of Fellows of the Royal Society, 1948-1949, 6: 115-45; see p. 133. Dale's verdict of the significance of this work is echoed by J S Fruton, Molecules and life. Historical essays on the interplay of chemistry and biology, New York, Wiley-Interscience, 1972, p. 340. By
}

\begin{abstract}
contrast, Holmes, while also viewing Fletcher and Hopkins' paper as a "landmark", sees their work as the culmination of an earlier tradition rather than as a new beginning in its own right; see F L Holmes, Between biology and medicine: the formation of intermediary metabolism, Berkeley, CA, Office for History of Science and Technology, 1992, pp. 45-7. Fletcher and Hopkins themselves, in the Croonian Lecture delivered to the Royal Society in December 1915, stressed the chemical simplicity of the respiratory process in muscle: "The actual chemical events which underlie the obvious manifestations of change in muscle - the contraction, the exhibition of fatigue, the recovery-we might then regard as relatively simple. We find similar indications in all progressive departments of biochemistry. The chemical events are not in themselves necessarily complex or obscure; the complexity is found in the conditions under which they occur." W M Fletcher and F G Hopkins, "The respiratory process in muscle and the nature of muscular motion', Proc. R. Soc., B, 1917, 89: 444-67, see p. 466.
\end{abstract}




\section{Harmke Kamminga and Mark W Weatherall}

This work with Fletcher further enhanced Hopkins' scientific reputation, and it both illustrated and further stimulated Hopkins' interest in the dynamic control of biological oxidation.

With these lines of research, most of Hopkins' long-term biochemical interests were in place: questions of chemical individuality and simplicity, of intermediary metabolism and chemical dynamics had been addressed in his own research by the end of the first decade of this century. This same research had focused Hopkins' interest on questions concerning the control and coordination of metabolic reactions associated with fundamental biological processes, questions which became central to the subsequent development of his dynamic biochemistry.

The aim of this brief outline has been to indicate the extent to which the central themes Hopkins used in his 1913 address drew on his own research. While the questions he addressed in his research were by no means unique, the use Hopkins made of them as rhetorical devices was distinctive. The multiple links between Hopkins' research and work being pursued elsewhere are evident from the numerous references to, for example, German and American work in Hopkins' own scientific papers and public lectures of the period, but they are beyond the scope of this paper. Our concern here is with the relationships between Hopkins' research and his public attempts to give biochemistry a firm foothold in Britain.

\section{From Research to Rhetoric}

The major scientific themes stressed in Hopkins' 1913 address were rooted in his own research, and did not emerge merely from his reading of the literature on protein metabolism as Robert Kohler suggests. ${ }^{23}$ Hopkins did read very widely, as indicated especially by the reviews he wrote for Richard Maly's Jahresbericht über die Fortschritte der Thierchemie, and later for the Annual reports of the Chemical Society. ${ }^{24}$ That wide reading alone, however, does not explain why Hopkins chose to emphasize the themes of chemical simplicity and dynamics rather than others. We propose that he chose them precisely because they had guided his own research for many years. Using these themes to give substance to his passionate pleas on behalf of biochemistry in 1913, he brought them into a broad public forum for the first time. Before then, scientists and physicians had known Hopkins primarily as someone eminently qualified to bridge scientific and clinical concerns. He had not previously presented himself as a man determined to promote a new fundamental science of biochemistry.

By 1913 Hopkins had been striving for at least a decade to establish a well-supported niche for his biochemical research in the University of Cambridge. ${ }^{25}$ As Kohler has shown, Hopkins had become increasingly disenchanted with his research facilities in the Physiological Laboratory. Under Foster's successor, J N Langley, Hopkins had to compete

\footnotetext{
${ }^{23}$ Kohler, op. cit., note 1 above, p. 74.

24 In the period 1901-1907, Hopkins wrote over 180 reviews for the Jahresbericht über die Fortschritte der Thierchemie, the leading review journal of physiological chemistry at that time; most of his contributions reported on British work in chemical pathology. He contributed the chapters
}

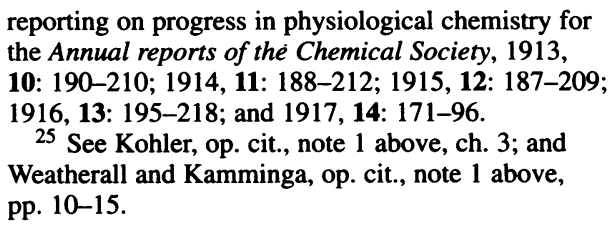
the Annual reports of the Chemical Society, 1913, 10: 190-210; 1914, 11: 188-212; 1915, 12: 187-209; 1916, 13: 195-218; and 1917, 14: 171-96.

25 See Kohler, op. cit., note 1 above, ch. 3; and Weatherall and Kamminga, op. cit., note 1 above, pp. 10-15. 


\section{The Making of a Biochemist}

fiercely for the most modest laboratory space, equipment and funds. The proper endowment of Hopkins' research became a desirable goal for all concerned, including Langley. Various attempts were made to achieve this end, from as early as 1904, but the parlous state of the University's finances and conditions set on a number of private bequests in the biological sciences conspired to exclude Hopkins. Given these long-term struggles, why did Hopkins wait until 1913 to introduce a novel rhetoric into the public domain, a rhetoric linked more intimately than before to his activities and aspirations in the laboratory? Did his lecture simply present a new intellectual synthesis that had been maturing over the years, or were there new strategic imperatives at work?

In fact, Hopkins' circumstances in Cambridge had changed substantially in 1912, when he moved from the Physiological Laboratory to a new institute administered under the University's School of Agriculture. This new opportunity arose at a time when the British government began to play an increasingly active role in the funding of universities and of science, in the context of a growing ideology of "national efficiency" in which science was enlisted to a degree unprecedented in Britain. ${ }^{26}$ Increased government funding of science had important repercussions within the University of Cambridge, where money from the government's recently created Development Fund was used to establish two new agricultural research institutes: the Institute of Plant Breeding and the Institute of Animal Nutrition. On invitation, Hopkins became co-director of the Institute of Animal Nutrition, with the Professor of Agriculture, T B Wood. It was a positive move for Hopkins: generous funding was provided for new laboratories, a group of talented research students was recruited to the institute, and Hopkins' colleagues at the institute held his work on dietary protein in very high regard. For the first time, Hopkins had the opportunity to guide a team of researchers investigating related subjects, and enjoyed good laboratory facilities.

Conditions might have seemed ideal for Hopkins, were it not for the fact that the Development Commission provided funds for the institute on the explicit condition that its research should be of direct benefit to British agriculture. Hopkins himself, in contrast, consistently gave priority to what he regarded as fundamental research, including his own work in the biochemistry of nutrition, which by then was centred on amino acid metabolism. For a decade he had been striving to make scientific contributions to the understanding of metabolic changes in fundamental biological processes. Highly regarded as that work was, Hopkins had been hampered by lack of resources until he joined the new institute. Having there experienced at first hand the pleasures of working with a lively group of reseachers in a well-endowed institutional setting, he may have become more confident that similar objectives could be achieved for basic research. With the continuing

\footnotetext{
26 G R Searle, The quest for national efficiency. A study in British politics and political thought, 1899-1914, Oxford, Blackwell, 1971. On state funding of science in Britain, see P Alter, The reluctant patron, transl. A Davies, Oxford, St Martin's Press, 1987 (which does not, however, discuss the Development Commission and
}

agricultural research); and R C Olby, 'Social imperialism and state support for agricultural research in Edwardian Britain', Ann. Sci., 1991, 48: 509-26. The background to the establishment of the Institute of Animal Nutrition and Hopkins' move to this institute are discussed further in Weatherall, op. cit., note 12 above. 


\section{Harmke Kamminga and Mark W Weatherall}

expansion of state funding for science, ${ }^{27}$ Hopkins may have decided that the time was ripe to seek support for the basic research he wished to pursue, on his own terms.

This hypothesis is consistent with the timing of Hopkins' earliest promotion in a public forum of biochemistry for its own sake, at the 1913 meeting of the British Association. As Section President for that year, he knew that he would be presenting the traditional presidential address to the Physiological Section. He chose to speak, not about subjects of immediate interest to physiologists, but about the directions that the new field of biochemistry should take, trying to appeal to young chemists in particular. In view of the high level of publicity conventionally given to the annual meetings of the British Association, Hopkins could be confident that reports of his lecture would reach a wide public. The contents of his address could certainly be expected to become known to those in positions of authority over science policy, and also to the potential recruits to biochemical research that Hopkins sought to inspire.

Accordingly, we propose that increased government support for scientific research, and ensuing changes in Hopkins' local situation within the University of Cambridge, motivated Hopkins to express in public his ambitions for dynamic biochemistry, and to do so on the particular occasion of the 1913 British Association meeting. At the level of Hopkins' own research, these ambitions were not new; what was new was Hopkins' evident determination to persuade others to share these ambitions with him.

\section{The Science and Rhetoric of Unification}

When Hopkins delivered his British Association address in 1913, he was not yet in a position to put into practice his ambitious programme of biochemistry. In 1914, however, a separate Department of Biochemistry was created by the University, and Hopkins was appointed to the Chair. ${ }^{28}$ As his staff expanded, research in the department increasingly followed the lines Hopkins had advocated, especially after World War I. Although the department's facilities and resources improved substantially following a large bequest from the Dunn Trustees, the chief new directions of research were in place before the department's move to the Dunn Institute of Biochemistry in May $1924 .^{29}$

In public lectures delivered after 1913, Hopkins not only returned to the major themes of his 1913 "manifesto", but also gave novel substance to these themes in presenting the results of his department's research. Of particular interest is Hopkins' and his colleagues'

\footnotetext{
27 The most pertinent example in this context is the establishment of the Medical Research Committee (later Medical Research Council), formed in 1913 under the National Insurance Act to support research on tuberculosis. That the MRC could soon broaden its remit dramatically into war-related investigations was due at least in part to active lobbying by the medical establishment for a broader funding role for the committee even before the MRC's formal inauguration. (This lobbying is not discussed in $\mathrm{J}$ Austoker and L Bryder (eds), Historical perspectives on the role of the MRC: essays in the history of the Medical Research Council of the United Kingdom and its predecessor, the Medical Research Committee, 1913-1953,
}

Oxford University Press, 1989.) Hopkins, as one of the founder members, directly helped to shape MRC policy, and also indirectly by securing the appointment of his Cambridge colleague Walter Morley Fletcher to the powerful post of Secretary to the committee.

${ }^{28}$ Kohler, op. cit., note 1 above, ch. 3 .

29 On the background to the creation of the Dunn Institute of Biochemistry, see R E Kohler, 'Walter Fletcher, F G Hopkins and the Dunn Institute of Biochemistry', Isis, 1978, 69: 331-55; but see Weatherall, op. cit., note 12 above, for information about the rapid expansion of the department immediately after the Great War. 


\section{The Making of a Biochemist}

shift away from research on the biochemistry of nutrition towards research on biological oxidation and its catalytic control, a shift that was virtually complete by the early $1920 \mathrm{~s}$. The move came about in the first instance through Hopkins' work on lactic acid formation in muscle. In these investigations, Hopkins was alerted to the presence in muscle of a sulphur-containing substance with reducing power, and subsequently obtained similar results for many other tissues. Between 1911 and 1921, Hopkins devoted much effort to the isolation of this reducing agent, in the light of his interest in tissue respiration. By 1916 Hopkins stated that, together with the regrouping of molecular units, oxidations "form the essential chapter in the chemical dynamics of metabolism". ${ }^{30}$ Eventually, in 1921, Hopkins succeeded in isolating an auto-oxidisable sulphydryl compound which he identified as a simple dipeptide of cysteine linked to glutamic acid, and which he named glutathione. ${ }^{31}$

\section{The Dynamics of Glutathione}

According to Hopkins, the sulphydryl group of the cysteine component of glutathione in its reduced state acts as a hydrogen "donator", while the disulphide group of its oxidized form acts as a hydrogen acceptor. Because of these properties, glutathione, depending on its state of oxidation, could mediate and control oxidation/reduction reactions involving other molecules. It was tremendously exciting to Hopkins that such a simple molecule as glutathione could play such a fundamental role in the dynamics of the cell. ${ }^{32}$ Glutathione provided a perfect exemplar of his conviction that biochemistry is concerned with simple molecules undergoing comprehensible reactions, underlying fundamental biological processes. Immediately, he began to present biological oxidation in his public lectures as a particularly fundamental problem in metabolism. ${ }^{33}$ Oxidation reactions are of fundamental importance, Hopkins stated, because they yield energy to the cell. They pose a problem, because these oxidations ultimately depend on molecular oxygen but involve molecules which do not react directly with molecular oxygen. Intermediary oxidations and associated reductions, catalysed by a host of specific enzymes, were being investigated intensively. To Hopkins, the finding of an non-enzymic tissue constituent that could act both as a hydrogen donor and as a hydrogen acceptor suggested an important role for at least one mechanism with more general oxidative functions.

When glutathione, as a "chemical individual", was found to be present in all the different tissues and organisms being studied in Cambridge, Hopkins became even more

\footnotetext{
${ }^{30}$ F G Hopkins, 'Newer standpoints in the study of nutrition', Trans. chem. Soc., 1916, 109: 629-49 (lecture to the Chemical Society, May 1916), see p. 649.

${ }^{31}$ F G Hopkins, 'On an autoxidisable constituent of the cell', Biochem. J., 1921, 15: 286-305. In note 1, p. 286, Hopkins recounts the background to this work.

32 See also the statement made by Hopkins' onetime colleague N W Pirie: “. . . a widely distributed reactive substance able to 'play a real part in cell dynamics' was just what his outlook on Biochemistry demanded." N W Pirie, 'Sir Frederick
}

\author{
Gowland Hopkins (1861-1947)', in G Semenza \\ (ed.), A history of biochemistry. Selected topics in the \\ history of biochemistry. Personal recollections. I, \\ Amsterdam, Elsevier, 1983, pp. 103-27, see \\ p. 121 . \\ ${ }^{33}$ The earliest instance is F G Hopkins, 'Some \\ oxidation mechanisms of the cell', Johns Hopkins \\ Bull., 1921, 32: 321-8. This was the first of two \\ lectures delivered by Hopkins in the Herter Series at \\ Johns Hopkins University in April 1921. The second \\ lecture was entitled 'The chemical dynamics of \\ muscle', ibid., 359-67.
}


outspoken about its fundamental and universal significance: glutathione unified organisms at the biochemical level, by providing a chemical mechanism with oxidative functions that was most probably common to all forms of life ${ }^{34}$ Here one could perhaps see an example of la simplicité cachée-a strong indication that, despite the enormous variety in detail, all living organisms are unified at a fundamental chemical level.

Hopkins' isolation of glutathione had another important consequence for the department's work. It led directly to the isolation of a widely distributed oxidative enzyme, xanthine oxidase, and work on this enzyme formed the starting point for a wideranging programme of research on specific enzymes controlling oxidations and reductions in many different species. ${ }^{35}$ Glutathione and xanthine oxidase provided the twin spurs for work bearing directly on biochemical control, and questions about control increasingly began to drive the research of Hopkins' department. The papers published by members of the department indicate this shift: during the 1920s roughly equal numbers of papers were published on the reaction pathways of intermediary metabolism and on the control of these reactions, with research papers on control becoming predominant towards the end of the decade. ${ }^{36} \mathrm{~A}$ great deal of work was published on the kinetics of metabolic reactions catalysed by enzymes, especially enzymes involved in tissue respiration. For Hopkins, the enormous variety of detailed work along these lines had a general significance:

In the dynamic equilibrium of the cell relative velocities must play a dominant part. Thermodynamic possibilities are controlled by kinetic actualities, and by command of the latter the cell maintains its integrity. ${ }^{37}$

The continuing interest in glutathione itself resulted in thirty-one papers over sixteen years, most of them with Hopkins as sole or joint author. (Hopkins continued to work on glutathione until his retirement in 1943, and co-authored two further papers on the subject, published in 1943 and 1945.) During the course of this period, the identification of glutathione as a dipeptide was revised (it was shown to be a tripeptide), and, more seriously for Hopkins, it became increasingly difficult to substantiate glutathione's fundamental and universal role in biological oxidation. ${ }^{38}$ Ironically, then, this major spur

\footnotetext{
34 See especially F G Hopkins, 'An oxidative mechanism in the living cell', Lancet, 1923, i: 1251-4 (lecture delivered at St Mary's Hospital, London, June 1923). Full of enthusiasm about the chemical technicalities of his subject, Hopkins here made few concessions to his medical audience.

${ }^{35}$ E J Morgan, C P Stewart and F G Hopkins, 'On the anaerobic and aerobic oxidation of $x$ anthin and hypoxanthin by tissues and by milk', Proc. $R$. Soc. B, 1922, 94: 109-31. The study of glutathione and of xanthine oxidase inaugurated Malcom Dixon's celebrated work in enzymology. Marjory Stephenson's long-term programme in microbial metabolism and enzymology was characteristic of the breadth of enzyme studies in Hopkins' department. See R E Kohler, 'Innovation in normal science: bacterial physiology', Isis, 1985, 76: 162-81.

36 Bound volumes of all papers published each year by members of the department are held in the
}

library of the Department of Biochemistry, University of Cambridge.

${ }^{37}$ F G Hopkins, 'On current views concerning the mechanisms of biological oxidation, with a foreword on the institutional needs of biochemistry', Skand. Arch. Physiologie, 1926, 49: 33-59 (Inaugural Lecture, International Congress of Physiology, Stockholm, 1926), see p. 50.

${ }^{38}$ For a brief review, see Pirie, op. cit., note 32 above. See also Keilin's statement, written in the 1960 s, that "at present no definite place can be assigned to glutathione in the main catalytic repiratory system in the cell". D Keilin, The history of cell respiration and cytochrome, Cambridge University Press, 1966, p. 128. Keilin, working at the Molteno Institute almost next door to Hopkins' institute, was a leading expert on cellular respiration and collaborated with Hopkins' colleagues Malcolm Dixon and Robin Hill in the 1930s. 


\section{The Making of a Biochemist}

to the experimental development of Hopkins' dynamic biochemistry into the direction of biological control, which resulted in such a fruitful programme of research, itself began to look like somewhat of a blind alley. References to glutathione disappeared from Hopkins' public lectures in the 1930s, but by then biochemical research in Cambridge and elsewhere had put plenty of other resources at Hopkins' disposal to illustrate his claims for dynamic biochemistry.

\section{Levels of Unification}

Hopkins continued to promote dynamic biochemistry persistently throughout the 1920 s and 1930s, the period during which he and his colleagues had the resources to put into practice an increasingly wide-ranging programme of biochemical research. In public lectures throughout this period, Hopkins presented admirably comprehensive reviews of the research being pursued in his institute (and, indeed, elsewhere), with shifts of emphasis in content as that research took new directions. At the same time, Hopkins' earlier major themes recur repeatedly, regardless of setting or audience: the dynamic side of biochemistry, the simplicity of chemical events underlying biological properties, and the importance of fundamental biochemical research.

The shifts in substance in these lectures are most evident in the late 1920s and the 1930s. Notably, with the expansion of the department's research on enzymes, Hopkins began to lay much more stress on the chemical specificity of catalytic reactions, now illustrated with concrete examples. ${ }^{39}$ Drawing on the same research, Hopkins also gave new substance and more prominence to the themes of coordination and control. ${ }^{40}$ Furthermore, when arguing for the autonomy of biochemistry-with respect to medicine, pathology, physiology, and indeed pure chemistry-he began to present that autonomy occasionally in institutional terms, with or without reference to his own institute. ${ }^{41}$ Invariably, however, Hopkins' statements about the special nature and needs of biochemistry convey his perception of its status as a unifying science of life: when it comes to the study of living things, biochemistry is the fundamental science with the strongest claims to universality.

Hopkins conveyed the message of unification in different forms, and consolidated its force by stressing new levels of unification successively, when the latest biochemical research provided him with pertinent examples. From 1913 onwards, he presented biochemistry as a science that unites chemistry and biology in its study of the chemical dynamics of the organism. We have also noted Hopkins' early insistence that, in its concern with dynamics over and above chemical analysis, biochemistry unifies the approaches of organic and physical chemistry. In the 1920s and 1930s, Hopkins presented

\footnotetext{
${ }^{39}$ For example, F G Hopkins, 'The problems of specificity in biochemical catalysis', Oxford University Press, 1931 (33rd Robert Boyle Lecture, Oxford, 1931). See also note 40 below.

${ }^{40}$ For example, F G Hopkins, 'Some aspects of biochemistry: the organising capacities of specific catalysis', Ir. J. med. Sci., July 1932, 333-50 (Second Purser Memorial Lecture, Trinity College, Dublin, June 1932).

41 The most explicit example is the foreword of
}

Hopkins, op. cit., note 37 above, which is reproduced in Teich with Needham, op. cit., note 1 above, pp. 518-20. Other examples are much weaker; see F G Hopkins, 'Address upon an unknown occasion (ca 1930)', in Needham and Baldwin, op. cit., note 1 above, pp. 201-5; and F G Hopkins, typescript of an untitled and undated lecture delivered in Leeds at the opening of a new chemical laboratory, in or after 1934 (Wellcome Unit for the History of Medicine, Cambridge). 


\section{Harmke Kamminga and Mark W Weatherall}

new illustrations in support of this theme. For instance, his department's work on the control of specific metabolic reactions by specific enzymes combined the organic chemical isolation and identification of enzymes, substrates and products involved in these reactions with the physicochemical elucidation of reaction kinetics. ${ }^{42}$

At the level of biochemical entities and processes, Hopkins looked for unity within diversity, common patterns underlying specificity, and began to present illustrative examples of this form of unification in the 1920s. For instance, with reference to the twenty different amino acids that are the structural units of protein, he stated that "among them unity of type is combined with great structural diversity in detail, the unity and diversity being equally important for the student of nutrition". ${ }^{43}$ With respect to mechanisms common to a range (perhaps even the whole range) of different organisms, the seminal example for Hopkins was provided by glutathione, as mentioned earlier. Thus strengthened in his convictions, he increasingly used the work of his department to suggest that, fundamentally, biochemical mechanisms of oxidation, catalysis, and so on, are similar in kind across the living world. At the same time, that conviction motivated comparative research in his department, to which Hopkins began to refer explicitly in the late $1920 \mathrm{~s}^{44} \mathrm{He}$ presented the general significance of that approach in terms of the quest for unity amidst diversity, which he viewed as a central pursuit of biochemistry:

If [biochemistry] is to arrive at significant generalizations, to decide, for example, what, in a chemical sense, is essential to the fundamental manifestations of life, and what is only essential for some specialized function, it must extend its studies in as wide a field as possible. ${ }^{45}$

Hopkins further used biochemistry to argue for the unity of science at the methodological level, expressing an ambition that was widespread in this period, both in science and in philosophy of science. ${ }^{46}$ Hopkins appealed to this theme especially in his stance against organicism. His persistent opposition to holistic notions of protoplasm may have seemed old-fashioned by the 1920 s and 1930 s, but his criticisms of organicism, then much in vogue, were timely. In countering charges that the analysis of organisms into chemical parts removes all biological meaning, Hopkins explicitly advocated methodological unification in the sciences: biology should not resort to explanatory principles that have no place in physics

\footnotetext{
42 Work on the mathematics of enzyme kinetics was introduced in the department by J B S Haldane in the 1920 s, work that was built upon especially by Malcolm Dixon.

${ }^{43}$ F G Hopkins, 'Newer aspects of the nutrition problem', New York, Columbia University Press, 1922 (Chandler Lecture, Columbia University, 1921), p. 11.

${ }^{44}$ For example, F G Hopkins, 'The centenary of Wöhler's synthesis of urea (1828-1928), Biochem. J., 1928, 22: 1341-8 (lecture, Biochemical Society, Cambridge, October 1928), see p. 1347. While there was a strong interest in comparative biochemistry in Hopkins' department, especially on the part of Joseph Needham and Ernest Baldwin, there is no evidence from publications that systematic research of a comparative nature was done by any of its members.
}

\footnotetext{
45 F G Hopkins, 'The influence of chemical thought on biology', Science, 1936, 84: 255-60 (lecture, Harvard University, September 1936), see p. 257. For a very similar statement, see F G Hopkins, 'Chemistry and life', London, Institute of Chemistry, 1933 (lecture, Institute of Chemistry, December 1932), p. 19. See also F G Hopkins, 'The naturalist in the laboratory', London Naturalist, 1936: 40-51 (address to the London Natural History Society, 1935).

46 On the 'Unity of Science' movement and its relations to logical positivism on the one hand and biology on the other hand, see V B Smocovitis, 'Unifying biology: the evolutionary. synthesis and evolutionary biology', J. Hist. Biol., 1992, 25: 1-65. For a classic example of a unified theory of metabolism, see A J Kluyver and H J L Donker, 'Der Einheit in der Biochemie', Chemie der Zelle und
} 


\section{The Making of a Biochemist}

or chemistry. ${ }^{47}$ Denying any categorical distinction between living organisms and the systems studied by physicists and chemists, Hopkins held that a full chemical description of the organism is in principle obtainable and will have biological meaning: such a description will not explain all properties of the organism, but without such a chemical description there will be no understanding of the organism at all. ${ }^{48}$

Hopkins declared himself particularly impressed by A N Whitehead's philosophy of reciprocal whole/part relationships throughout nature: ${ }^{49}$ whereas the organicist sets up insuperable barriers in the study of nature, Whitehead denies any difference in principle between the organization of an atom, a molecule, or a living organism, and argues that each should be studied in terms of its specific internal and external relations. Hopkins thoroughly approved of Whitehead's notion of events, as opposed to static entities, as the basic units of reality, a view that was consistent with dynamic biochemistry precisely because of its concern with molecular events, not merely substances. ${ }^{50}$ On that perspective, Hopkins could maintain that the principles of dynamic biochemistry, unlike organicism, respect and indeed promote the unity of science.

At the level of subject boundaries, Hopkins presented biochemistry as a science that unites the interests of numerous disciplines. When he addressed clinicians or pathologists, he spoke of the benefits that fundamental biochemical research had to offer them. ${ }^{51}$ Physiologists were told of the new understanding that could be gained by studying the chemical dynamics of life in general, not merely in relation to the physiology of animals and their organs. ${ }^{52}$ To chemists, Hopkins stressed the special interest, and challenge, of investigating the chemical behaviour of the heterogeneous, organized systems presented by living organisms. ${ }^{53}$ Hopkins' recurring characterization of biochemistry as a scientific borderland deserves further examination in this context.

\section{Biochemistry as Borderland: Demarcation or Unification?}

First used in 1913, the borderland metaphor reappeared periodically in Hopkins' lectures up to his last major public address, the Linacre Lecture delivered in Cambridge

$\overline{\text { Gewebe }}, 1926,13: 134-90$. See also the lecture by one of Kluyver's most influential disciples, C B van Niel, 'The "Delft School" and the rise of general microbiology', Bact. Rev., 1949, 13: 161-74. Kluyver had frequent contact with Hopkins' colleague Marjory Stephenson, their work on microbial metabolism being of great mutual relevance and interest.

47 See especially F G Hopkins, 'A lecture on organicism (1927)', in Needham and Baldwin, op. cit., note 1 above, pp. 179-90. Hopkins here referred to Johan Hjort's book Unity of science, London, Gyldenhal, 1920, which he admired greatly. (Hjort, in his book, quoted some passages from Hopkins' 1913 address to the British Association, which he thought had bearing on the relations between biological organization and mechanism.) Hjort, a Norwegian zoologist, worked in Hopkins' department for several years in the late 1910s and early 1920 s.
48 Ibid. Also Hopkins, op. cit., note 39 above, p. 20: "[The biochemist's] may not be the last word in the description of life, but without his help the last word will never be said."

${ }^{49}$ Hopkins, op. cit., note 47 above; Hopkins, op. cit., note 40 above; and Hopkins, 1936, op. cit., note 45 above.

50 Especially Hopkins, 1936, op. cit., note 45 above.

51 F G Hopkins, 'Recent advances in science in relation to practical medicine and the nutritional requirements of the body', Lancet, 1921, i: 1-26 (Huxley Lecture, Charing Cross Hospital Medical School, November 1920); F G Hopkins, 'The clinician and the laboratory worker (1931)', in Needham and Baldwin, op. cit., note 1 above, pp. 206-10.

52 Especially Hopkins, op. cit., note 37 above.

53 Hopkins, op. cit., note 39 above; Hopkins, c. 1930 , op. cit., note 41 above. 


\section{Harmke Kamminga and Mark W Weatherall}

in 1938. In the Huxley Lecture presented in Birmingham in 1924, he talked of biochemistry as a borderland between chemistry and biology which needs "the practical help of workers with diverse qualifications". ${ }^{4}$ By then Hopkins could state that traffic across the borders on either side was setting in, expressing satisfaction also at the "magnificent endowment" (and the implicit recognition) that the subject of biochemistry had just received in Cambridge with the newly opened Dunn Institute. While he presented this borderland science as "a fitting meeting place for many minds and for many university faculties", Hopkins also stated that it "calls for special discipline and for special equipment". 55 The force of the metaphor, then, is that this borderland brings together chemists and biologists to engage in pursuits that are distinct from practices in the bordering nations: biochemistry is special.

As Hopkins suggested in 1927, biochemistry is special because the inhabitants of this borderland must be capable of learning the language and methods of both chemistry and biology. ${ }^{56}$ The chemist may be best equipped to cultivate its soil, but "it is the biologist who best knows the lay of the land". The advance of biochemistry should encourage biologists to picture always "the molecular events which underlie the changes of form and visible appearances which interest them" and it should persuade chemists that the study of molecular events becomes especially interesting when these events are "organised and coordinated in systems involving changing form and elaborate structure".

In this instance, Hopkins' stress on the benefits that the borderland of biochemistry can bring to chemists and biologists alike served a specific function. The bulk of the lecture is devoted to a critique of organicism. To this end, Hopkins stressed that biochemistry is neither simply a branch of applied chemistry, nor does it assume the whole organism to be an irreducible entity (an assumption that would imply the futility of biochemical endeavour). Instead, the borderland of biochemistry combines the aim of describing the activities of living organisms in terms of physics and chemistry with a biologically informed appreciation of the organization of the living organism. While the crossing of frontiers carries the risk of producing "a confusion of tongues", 57 special training can be directed at mutual comprehensibility among the inhabitants of a borderland. In pursuing this aim, biochemistry is uniquely capable of providing descriptions that "possess the merits due to the use of a more universal scientific language". 58

The thesis that borderlands have their own special problems, techniques and training can be used to set these regions apart from the neighbouring nations, as Hopkins did on one occasion. Towards the end of a lecture on the achievements of organic chemistry, delivered around 1930, Hopkins introduced biochemistry as a "borderland pursuit" distinct from organic chemistry. ${ }^{59}$ While organic chemists could provide structural knowledge about molecules, it was the study of the chemical dynamics of living systems that had become the special area of the biochemist. Furthermore, to Hopkins it was precisely this concern with dynamics that justified the position of biochemistry "as a separate branch of science":

\footnotetext{
54 F G Hopkins, 'Biochemistry: its present position and outlook', Lancet, 1924, i: 1247-52 (Huxley Memorial Lecture, University of Birmingham, May 1924), see p. 1248.

55 Ibid., p. 1252.
}

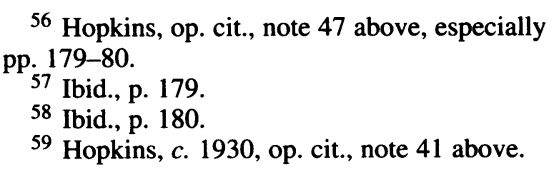


Its own special endeavour as a borderland science must be to study the chemical dynamics of living systems, to follow so far as may be possible the function and fate of each constituent amid the multitudinous reactions which underlie the manifestations of life, and the mechanisms which control these reactions. ${ }^{60}$

This very specialization, however, increased the biochemist's reliance on the organic chemist:

If he has spent his time in making himself a good biochemist on the lines I have defined, he must usually remain at best an amateur in dealing with the problems of molecular structure. There was never a case in which progress can be better secured by a wise division of labour. ${ }^{61}$

Hopkins ended by welcoming the fact that eminent organic chemists had turned their attention to the structure of substances of biological importance, mentioning recent successes with hormones and vitamins in particular. He added pointedly, however, that physiologists and biochemists had first discovered the existence of these substances and studied their functions, implying that the reliance worked both ways. On this occasion, the "borderland science" of biochemistry was clearly presented as being autonomous with respect to organic chemistry, but still Hopkins implied that specialization and division of labour should not lead to closed borders.

For Hopkins, borderlands were fertile precisely because borders were not closed. He stressed the metaphoric fertility of borderlands from his Huxley Lecture of 1924 to his Linacre Lecture of 1938: not only do explorers of scientific borderlands "usually find work to do which would not be done by those whose main interests are confined to one of the fields in question", 62 it is in such fertile soil that conceptual innovation is to be expected: "where sciences meet there growth occurs . . . In scientific borderlands not only are facts gathered that are often new in kind, but it is in these regions that wholly new concepts arise."63 Even in 1938, Hopkins still expressed the hope that his younger colleagues in biochemistry "will always justify their special designation and strive as far as is humanly possible to be biologists as well as chemists". 64

In conclusion, the borderland metaphor, as used by Hopkins, served purposes of unification in the sense that the coming together of chemists and biologists creates a new, unified science of life. Simultaneously, the metaphor served purposes of demarcation in the sense that this new science of life is distinct, in its practices and concerns, from both mainstream chemistry and mainstream biology. It is distinct precisely because it unifies and unification brings novelty. Even when Hopkins stressed the special features of his borderland science, however, demarcation never took the strong form of erecting impenetrable frontiers. The crossing of its borders from neighbouring domains makes the borderland fertile and creates the conditions for the union of chemical skills and biological instinct that characterizes dynamic biochemistry.

60 Ibid., p. 204.

61 Ibid., p. 205.

62 Ibid., p. 204.

63 F G Hopkins, 'Biological thought and chemical thought. A plea for unification', Lancet, 1938, ii:
1147-50; 1201-4 (Linacre Lecture, Cambridge,

1938), see p. 1204.

64 Ibid., p. 1204. 


\section{Harmke Kamminga and Mark W Weatherall}

\section{The Uses of History}

Unification also featured prominently in Hopkins' appeals to history, which were legion in his writings and public lectures. From 1913 until the late 1930s, he looked at the past, presenting the achievements of investigators such as Friedrich Wöhler, Justus Liebig and Felix Hoppe-Seyler as a progressive movement towards the kind of programme he was promoting: a programme which Hopkins presented, not simply as a further step along a linear route of progress, but as a novel synthesis of earlier developments, a synthesis which should guide biochemical research henceforth. By analogy with his use of the borderland metaphor, Hopkins used history to bring traditions together, and yet set dynamic biochemistry apart as a distinct, new endeavour.

Hopkins conveyed this central message by pointing out the limitations of nineteenthcentury approaches to the chemistry of life, and by setting up in contrast recent insights gained in the study of the chemical dynamics of biological processes. ${ }^{65}$ The limitations of earlier approaches that Hopkins highlighted were numerous and operated on several different levels. In 1913, he attributed the slow progress made in animal chemistry since the pioneering work of Liebig mainly to the shortage of workers in the field, and this he attributed, in turn, to general trends in organic chemistry: in the nineteenth century, organic chemistry was advanced above all by building the foundations of structural theory and by perfecting the art of synthesis. On the other hand, regions important for biochemistry were left unexplored. Notably the art of analysis of organic substances present in complex mixtures lagged behind. In addition, despite the important work of Thomas Graham, chemists devoted little effort to the study of colloids, and it was, after all, the colloidal state of matter which "dominates the milieu in which vital processes progress". ${ }^{66}$ Furthermore, after the work of Berzelius, organic chemists long neglected the study of catalysis, while it was now recognized that the influence of catalysts "is responsible for all chemical change as it occurs in living matter". ${ }^{67}$ Change had set in, however, not only in the form of new analytic work on biological materials, but also in a greater emphasis on dynamics:

In numerous centres, instead of only in a few, quite other aspects of [organic chemistry] were taken up: in particular, the study of the dynamic side of its phenomena. The historian will come to recognise that a considerable revolution in the chemical mind coincided roughly with the beginning of this century. ${ }^{68}$

In the 1913 address Hopkins also criticized the nineteenth-century notion that the unit of living matter is a very large and labile molecule, an assumption which he considered "inhibitory to productive thought" ${ }^{69}$ In contrast to this view, Hopkins presented the living cell as a highly differentiated system of co-existing phases of different constitutions, the dynamics of which could be elucidated by the biochemist. Bringing together the resources of organic and physical chemistry enabled the biochemist to investigate the cell with

\footnotetext{
${ }^{65}$ For illustrative examples of the new approach, Hopkins drew mostly on German and American work, besides his own. Among those whose work he mentioned with approval in early public lectures were Emil Fischer, Franz Hofmeister, Albrecht

Kossel, Otto Folin and Donald van Slyke.
}

66 Hopkins, op. cit., note 4 above, pp. 653-4.

67 Ibid., p. 654.

${ }^{68}$ Ibid.

69 Ibid., p. 662. 
chemical rigour and at the same time do justice to the complexities of biological organization. In this new endeavour, chemical skill and biological instinct had to be united.

An interesting illustration of the way in which the unification of chemistry and biology entered into Hopkins' use of history is provided by a set of four wood carvings in the library of the Dunn Institute, opened in 1924, which were commissioned especially by Hopkins and are still in place today. While there is no surviving documentation which explains why Hopkins chose the particular subjects depicted, the iconography of the carvings is suggestive of their significance for Hopkins. They depict four individuals (see plates), as follows:

John Mayow (1641-1679), admired by Hopkins for his studies of the chemistry of respiration. ${ }^{70}$ The carving depicts Mayow's volume of treatises Tractatus quinque medicophysici $(1674),{ }^{71}$ which presents his theory that respiration serves primarily to convey a supply of nitrous particles from the air to the blood, and that these nitro-aerial particles constitute the substance of animal spirits: they are essential for life, for the heart beat, and for muscle contraction. Mayow's experiments on respiration are represented by a candle and a bell (perhaps meant as an allusion to the inverted bell-jars used by Mayow in his experiments). In nineteenth- and early-twentieth-century Britain, Mayow was widely seen as having anticipated Lavoisier's insights into the role of oxygen in combustion and in respiration, and it is very likely that Hopkins had been exposed to this (problematic) interpretation through reading Foster's Lectures on the history of physiology. Mayow may have seemed an apt choice if Hopkins deemed it tactful to pay tribute to early British work on respiration, a subject of central biochemical interest.

Thomas Graham (1805-1869), celebrated by Hopkins as the "father of colloid chemistry". This subject, represented in the carving by Graham's dialyser and (anachronistically) by his book Elements of chemistry (1842), was an important one for Hopkins, which he discussed frequently. To Hopkins, it was "the colloidal apparatus [of the cell] in which the dynamic events of life occur". ${ }^{72}$ Colloids were crucial for the organization of biochemical events: they provide the architecture which compartmentalizes and coordinates the metabolic reactions of the cell. ${ }^{73}$ It is plausible that

\footnotetext{
${ }^{70}$ Fletcher and Hopkins, op. cit., note 22 above, p. 444; and Hopkins, op. cit., note 54 above, p. 1247. This second mention of Mayow came in Hopkins' Huxley Memorial Lecture of May 1924, the very month that the Dunn Institute of Biochemistry was opened.

${ }^{71}$ This work was re-issued in English translation by the Alembic Club in 1907: J Mayow, Medicophysical works, transl. A Crum Brown and L Dobbin, Edinburgh, Alembic Club Reprints, No. 17, 1907. Mayow's contributions to "the physiology of respiration" were discussed at length by $M$ Foster, Lectures on the history of physiology, Cambridge University Press, 1901, pp. 185-99.

72 Hopkins, op. cit., note 43 above, p. 9 . Among numerous other examples from different periods, see Hopkins, op. cit., note 4 above; and op. cit., note 40 above. With respect to the unification issue, it is of interest that Hopkins asserted that biologists in the
}

twentieth century had provided chemists with new insights into the colloidal state of matter; see F G Hopkins, 'Introductory remarks, Faraday Society discussion on the structure of living matter', Trans. Faraday Soc., 1930, 26: 770-1.

${ }^{73}$ On biochemistry and the study of colloids in this period, see N Morgan, 'The strategy of research programmes: reassessing the "Dark Age" of biochemistry, 1910-1930', Ann. Sci., 1990, 47: 139-50. On the significance of the colloidal geography of the cell for the Cambridge school of biochemistry, see M Teich, 'From "enchyme" to "cyto-skeleton": the development of ideas on the chemical organization of living matter', in M Teich and $\mathrm{R} M$ Young (eds), Changing perspectives in the history of science: essays in honour of Joseph Needham, London, Heinemann, 1973, pp. 439-71, especially pp. 461-71. 


\section{Harmke Kamminga and Mark W Weatherall}

Hopkins was also struck by Graham's explicit distinction between the colloidal and the crystalloid states of matter as being "dynamic" and "static", respectively.

Justus Liebig (1803-1873), regarded by Hopkins as "the father of modern animal chemistry". ${ }^{74}$ However, Hopkins also criticized Liebig's "proteid theory" and thought that Liebig's work on animal nutrition had a very flimsy experimental basis. ${ }^{75}$ This verdict has interesting bearing on the depictions, which focus on Liebig's work in agricultural chemistry rather than animal nutrition. In the book represented here, Agricultural chemistry (1841), Liebig did plead for the importance of chemistry for physiology, but it is Liebig's Animal chemistry (1842), which is commonly hailed as having heralded the scientific study of animal nutrition and metabolism. It is plausible that Hopkins did not wish to honour the flawed studies of "metabolism in block" presented in the latter work. The stress on agriculture in the carving is reinforced by the sheaves of corn. Strikingly, Liebig the chemist is surrounded by biological objects; the prime message is one of unification.

Louis Pasteur (1822-1895), admired by Hopkins for having transformed medicine through his fundamental scientific contributions. ${ }^{76}$ This carving, uniquely among the four, depicts both chemical and biological research objects. Notable are the two dissymmetric forms of paratartrate crystals ${ }^{77}$ which Pasteur was the first to separate from "racemic acid" and which formed the basis for his theory of molecular dissymmetry. Pasteur's studies of these crystals were initially undertaken entirely from a physicochemical perspective, but. they provided a bridge with the biological domain when he showed that only one of two dissymmetric forms of certain organic molecules is used as a nutrient by microorganisms. The carving further depicts grapes, alluding to Pasteur's studies of microbial diseases of wine (possibly even to "racemic acid"), and a barking dog, referring to Pasteur's work on the rabies vaccine. Here both chemistry and biology are represented through the work of one man.

When Hopkins commissioned the carvings in the early 1920 s, he clearly wished to portray a tradition for biochemistry, as a subject with twin roots in chemistry and biology. There are visual hints that these roots were beginning to merge in the case of Liebig and Pasteur. (The top corners of the carvings, depicting illumination from candle flames to blazing torches, even suggest progressive enlightenment.) Hopkins' perception of the limitations of that merging became explicit later, when he criticized both Liebig and Pasteur for failing to achieve a true synthesis between chemistry and biology. Liebig became his most prominent example of a chemist who lacked "physiological knowledge"

\footnotetext{
74 Hopkins, op. cit., note 4 above; op. cit., note 54 above. Liebig often advocated the fusion between chemistry and physiology and occasionally even used a metaphor akin to Hopkins' "borderland", writing that when two sciences "come into contact at their boundaries", generally "a new science arises on the debatable land between them, which combines in itself the objects and the modes of viewing the phenomena of both." See J von Liebig, Familiar letters on chemistry, London, Taylor, Walton \& Maberly, 3rd edn, 1851, p. 249.

${ }^{75} \mathrm{~F}$ G Hopkins, 'The utilisation of proteids in the animal', Sci. Prog., 1906, 1: 159-76, see pp. 159-61;
}

and F G Hopkins, 'Four lectures on the significance of variations in the constituents of the urine. Lecture II', Guy's Hosp. Gaz., 1907, 21: 383-8, see p. 384.

${ }^{76} \mathrm{~F}$ G Hopkins, 'Medicine and experimental science', in A C Seward (ed.), Science and the nation, Cambridge University Press, 1917 , pp. 228-55, see pp. 229, 235-40.

77 In view of the difficulty of depicting the crystal's mirror images, Hopkins sent the architect of the Dunn Institute a textbook illustration, to be given as a guide to the carver (Hopkins to Edwin Cooper, 7 February 1923, University of Cambridge archives, BCHEM3/1(17)). 


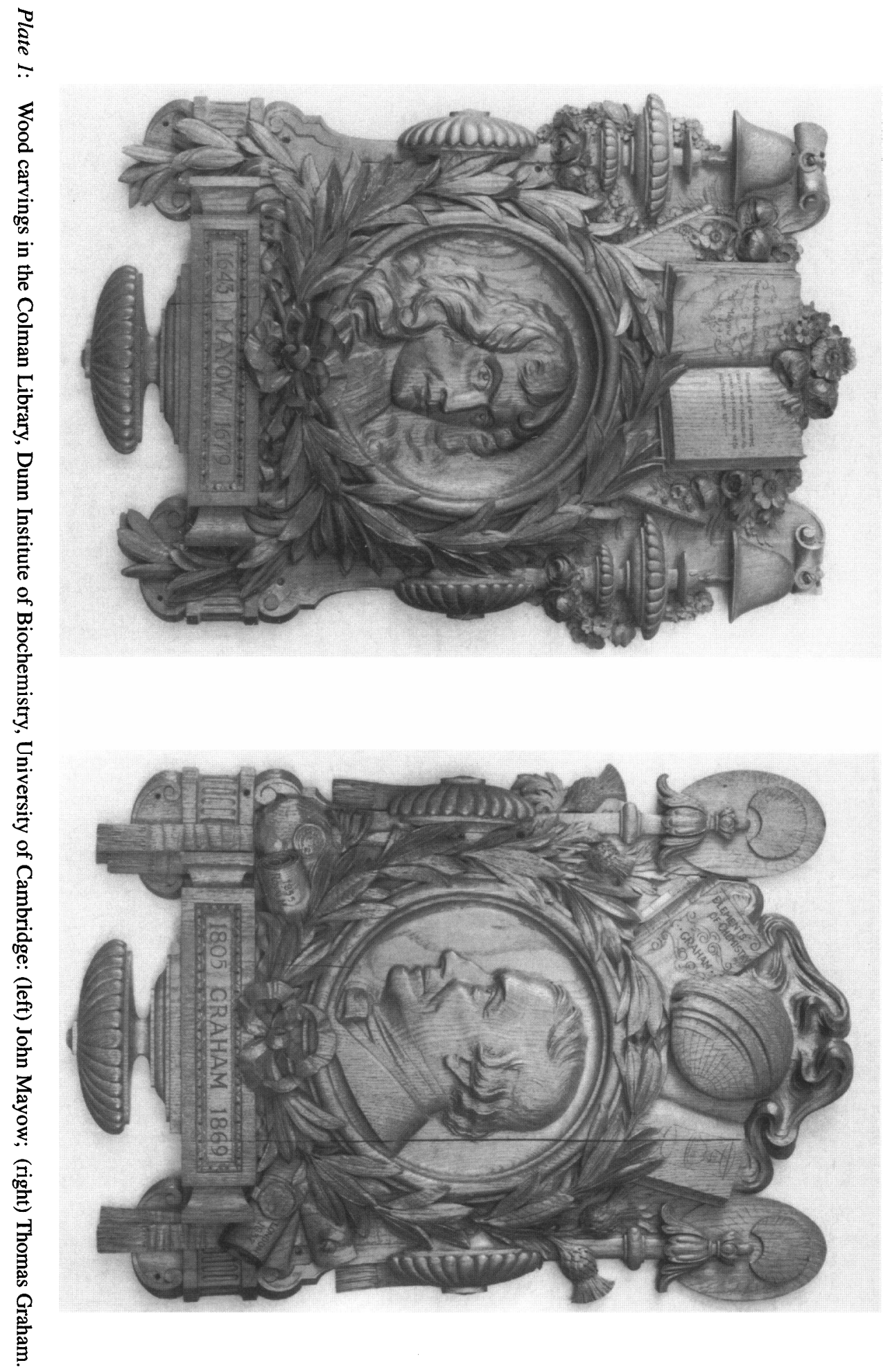




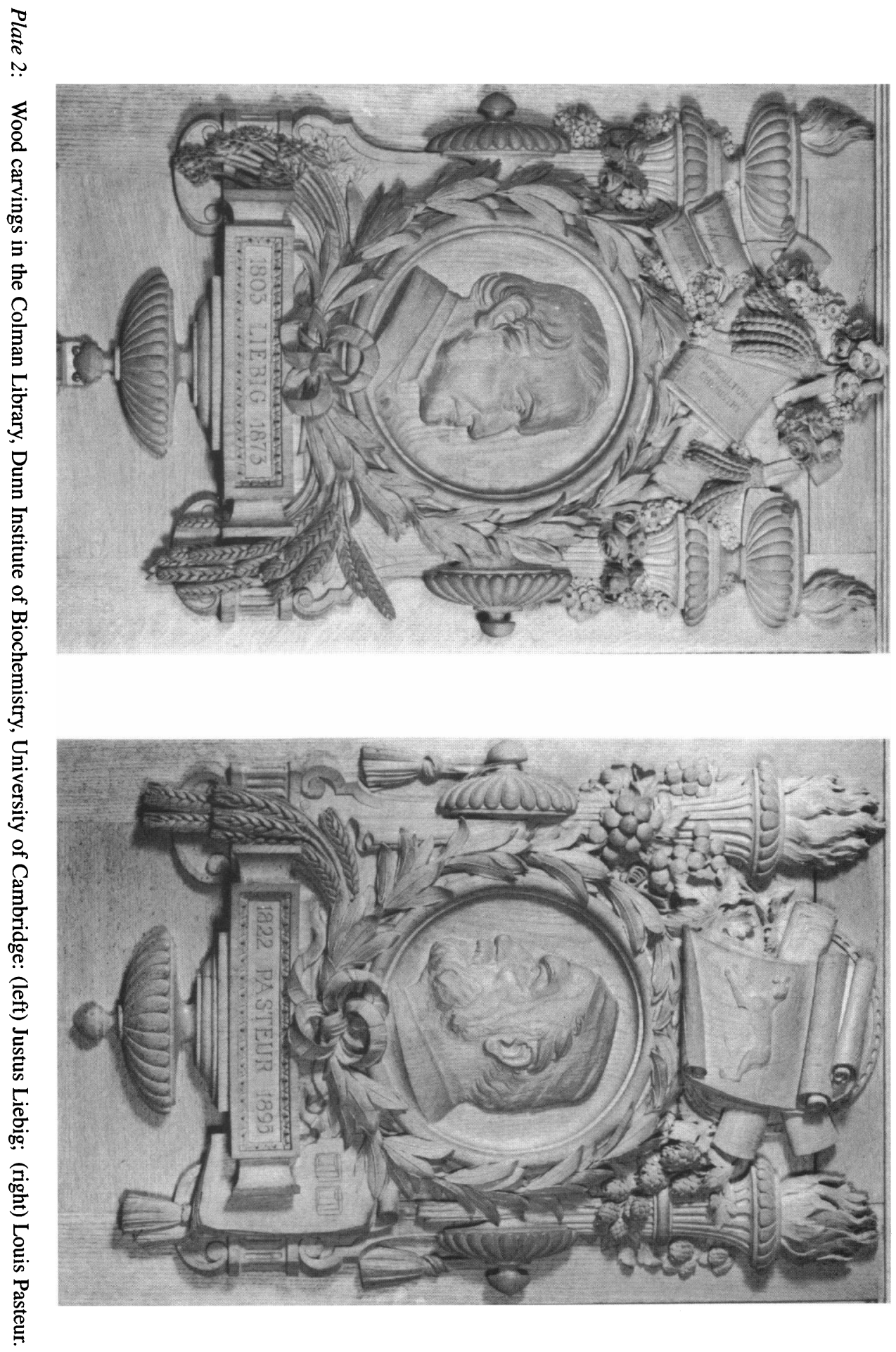


and "a biologist's instincts", who remained a chemist through and through without ever showing any scientific appreciation of the problems of biological organization. ${ }^{78}$ Pasteur's failing was the opposite: once Pasteur entered the biological domain after his researches in physical chemistry, Hopkins claimed, he became "almost too much the biologist" ${ }^{79}$ In particular, Pasteur held that, except for inputs and outputs, the chemical reactions of metabolism could not be studied meaningfully in isolation from the living organism as a whole.

In both cases, the intellectual obstacles had been broken down by the new biochemistry, which Hopkins throughout presented as a product of the twentieth century. As he put it in 1933:

As a progressive scientific discipline [biochemistry] belongs to the present century. From the experimental physiologists of the last century it obtained a charter, and, from a few pioneers of its own, a promise of success; but for the furtherance of its essential aim that century left it but a small inheritance of facts and methods. By its essential or ultimate aim I myself mean an adequate and acceptable description of molecular dynamics in living cells and tissues. ${ }^{80}$

Hopkins generally used history with care: the tradition he presented was a progressive one and, in its emphasis on greatly admired men of the past, a respectable one; at the same time, that tradition was presented as being deeply flawed, especially with respect to rifts between chemical and biological outlooks. Dynamic biochemistry could then be set up as a truly innovative endeavour, as a synthesis that overcame previous obstacles. ${ }^{81}$ In this way, Hopkins constructed a respectable tradition-a past-in order to create a future for his novel, and unifying, dynamic biochemistry.

\section{Hopkins' Model of Dynamic Biochemistry}

The picture that we have arrived at is that Hopkins consistently aimed to develop and promote dynamic biochemistry as the fundamental science of life-a new science in which chemistry and biology are unified. As we have shown, the unification envisaged by Hopkins did not consist simply in the application of chemical techniques to biological objects, but aimed at an intellectual synthesis-a synthesis of chemical and biological outlooks in the study of living things. Nor was this the only level of unification stressed by Hopkins: biochemistry unifies organic and physical chemistry in its study of the chemical dynamics of the cell; at a fundamental chemical level, it unifies biological processes across the living world; and it promotes the unity of science at the level of methodology.

We have noted that Hopkins remained a propagandist for dynamic biochemistry until the end of his career. This is somewhat puzzling if Hopkins is considered above all as a discipline builder in the institutional sense: ${ }^{82}$ given that his school was flourishing, why

\footnotetext{
78 Hopkins, op. cit., note 44 above, p. 1344; and F G Hopkins, 'The study of human nutrition: the outlook today', J. R. Soc. Arts, 1935, 83: 572-91 (Trueman Wood Memorial Lecture, Royal Society of Arts, February 1935), see p. 575.

79 Hopkins, 1936, op. cit., note 45 above, pp. 255-6.
}

\footnotetext{
${ }^{80}$ F G Hopkins, 'Some chemical aspects of life', Report of the Proceedings of the BAAS, 1933, pp. 1-24 (Presidential Address, British Association for the Advancement of Science, Leicester, 1933), see p. 3.

${ }^{81}$ For a very skilful example, see Hopkins, op. cit., note 44 above.

${ }^{82}$ Kohler, op. cit., note 1 above, chs 3 and 4.
} 


\section{Harmke Kamminga and Mark W Weatherall}

did Hopkins apparently feel the need to continue making propaganda for biochemistry throughout the 1920s and 1930s? One might expect Hopkins to have felt reasonably confident about the survival of the discipline in Cambridge. Research at his institute was thriving, its teaching programmes were well entrenched in the University, and over the years his younger colleagues had been putting the principles that he advocated into practice with unquestionable commitment. They had also contributed actively to the dissemination of dynamic biochemistry, not least through the widely read books they published. ${ }^{83}$ Yet Hopkins' propaganda continued, right up to his last major public address, the Linacre Lecture of 1938, which has the highly significant title of 'Biological thought and chemical thought: a plea for unification' ${ }^{84}$

Given that Hopkins was already well into his seventies when he presented many of his later addresses, the suspicion may arise that he was simply getting old and beginning to repeat himself, trying to fight battles that had already been won. His lectures from the 1930s, however, do not read at all like the tired repetitions of an éminence grise well past his prime; they are fresh and full of vigour. The question arises, then, what was driving Hopkins? We suggest that Hopkins continued to feel the need for "evangelism" precisely because his prime concern was the promotion of a distinctive approach to biochemistry which not only remained atypical, but which was not properly understood even by Hopkins' closest peers among the British scientific establishment.

Despite the international reputation which Hopkins and his colleagues in Cambridge enjoyed, and despite the influence which his school had on students and on visiting scientists, Hopkins' unified dynamic biochemistry did not in the interwar years serve as a model that was, in practice, emulated widely elsewhere. Moreover, as we aim to show in our second paper, outside Hopkins' institute dynamic biochemistry was widely interpreted in a much narrower sense than he intended. Instead of Hopkins' fundamental science of life encompassing the chemical dynamics of all biological processes, dynamic biochemistry was often interpreted as being concerned solely with the study of intermediary metabolism and of the action of enzymes implicated in metabolic reactions, especially with an eye to human metabolism and ultimate medical applications. Most seriously, as we shall show, this narrower interpretation was current among a group of eminent physiologists with decision making powers in Cambridge University and in funding bodies. Under these circumstances, it seems reasonable that Hopkins continued to feel the need to present his dynamic biochemistry as an exemplar.

In his disciplinary history of biochemistry, Kohler concludes that the wide-ranging programme in biochemistry that Hopkins was able to put into place in Cambridge was unusual, certainly in interwar Britain, because of the special institutional arrangements available to Hopkins. In most other British universities, biochemistry and chemical

\footnotetext{
83 Notably J B S Haldane, Enzymes, London, Longmans, Green, 1930; M Stephenson, Bacterial metabolism, London, Longmans, Green, 1930; J Needham, Chemical embryology (3 vols), Cambridge University Press, 1931; E F Baldwin, An introduction to comparative biochemistry, Cambridge University Press, 1937; and E Holmes, Metabolism of living tissue, Cambridge University Press, 1937. The last two books were written
}

especially for undergraduates taking the Part I course in biochemistry, which began in 1934, as part of their second year of the Natural Sciences Tripos. Baldwin made explicit reference to the tradition of "dynamic biochemistry" in the title of his widely used textbook Dynamic aspects of biochemistry, Cambridge University Press, 1947, and subsequent editions. (This textbook was dedicated "To Hoppy".)

84 Hopkins, op. cit., note 63 above. 


\section{The Making of a Biochemist}

physiology remained tied institutionally to medicine, and consequently played more of a service role in teaching and in research; in medical faculties, there was no place for programmes of "general biochemistry". 85 The institutional arrangements enjoyed by Hopkins in the 1920s and 1930s indeed gave him the opportunity to put into practice his far-reaching ambitions for biochemistry. Not wishing to ascribe intentions on the basis of outcomes, however, we question whether Hopkins himself deliberately set out to create these institutional arrangements. Was Hopkins in fact "a visionary entrepreneur", as Kohler calls him $?^{86}$ In our treatment so far, Hopkins may come across as visionary, but the pursuits of an entrepreneur in the political economy of science are not much in evidence. We have seen how actively Hopkins promoted dynamic biochemistry until the end of his career. In Kohler's account of Hopkins as a highly successful discipline builder, by contrast, Hopkins comes across as a curiously passive figure. We hope to resolve this tension between the passive and the active Hopkins in our second paper, where we look more closely at the reputations ascribed to Hopkins, including his reputation as a discipline builder.

With respect to Hopkins' "vision" of biochemistry, we have found that it was always more than an idealist vision: it had material roots in Hopkins' own research. Furthermore, this vision did not remain static, but changed over time: as Hopkins' programme of research changed, so his vision of biochemistry acquired new substance and then motivated new lines of research. There was a robust core to this vision, however, which found expression in Hopkins' never-ceasing emphasis on chemical dynamics. His longterm concern with chemical change as opposed to chemical constitution alone, with reaction kinetics, coordination and control in addition to chemical analysis, is the persistent feature both of Hopkins' research and of his promotion of biochemistry.

We do not, therefore, draw a contrast between a vision of "dynamic biochemistry" and a programme of "general biochemistry", as Kohler does by implication. In both cases, we feel that "dynamic biochemistry" expresses most aptly the force of Hopkins' intentions. Hopkins did talk of "general biochemistry" himself, but on only one public occasion. ${ }^{87}$ That was the 1926 International Congress of Physiology in Stockholm, where Hopkins presented the inaugural lecture, on mechanisms of biological oxidation. In the introductory part of this address, Hopkins put in the strongest public plea of his entire career for separate institutes of "general biochemistry", presenting his own institute in Cambridge as a modest but successful "experiment" in this direction. It is important to

85 These medically motivated traditions in biochemistry should, however, be evaluated on their own terms. See S Sturdy, 'Medical chemistry and clinical medicine. Academics and the scientisation of medical practice in Britain, 1900-1925', in I Löwy

(ed.), Medicine and change: historical and sociological studies of medical innovation, Montrouge, John Libbey Eurotext, Paris, Editions INSERM, 1993, pp. 371-94. Sturdy argues persuasively that early twentieth-century British medical chemistry should not be looked upon as "immature biochemistry", but as a scientific programme that was successful in its own terms of providing a service to physicians, clinicians and public health officials.

\footnotetext{
${ }^{86}$ Kohler, op. cit., note 1 above, p. 92.

87 Hopkins, op. cit., note 37 above. The phrase was also used in a letter to Fletcher in June 1919, where Hopkins expressed his wish to develop a Part II course in "General Biochemistry" (MRC PF106). (Part II is the specialized course in that subject to which the entire third year is devoted by undergraduates taking the Natural Sciences Tripos at Cambridge. A Part II course in biochemistry began in 1924.) Significantly, the phrase "general biochemistry" is not used once by Hopkins' colleagues in Needham and Baldwin, op. cit., note 1 above.
} 


\section{Harmke Kamminga and Mark W Weatherall}

note the particular context of Hopkins' lecture: addressing the audience at an international congress of physiology, he contrasted the physiologist's concern with animal studies and the biochemist's concern, as Hopkins saw it by then, with all living material:

No full understanding of the dynamics of life as a whole, no broad and adequate views of metabolism, can be obtained save by studying with equal concentration the green plant and microorganisms as well as the animal. ${ }^{88}$

Hopkins' advocacy of the study of biochemical processes across different species, from bacteria to mammals, here served the specific purpose of raising the status of biochemistry among physiologists. 89 "General biochemistry" was presented as offering the only route towards fundamental generalizations applying across the living world. Underlying this promise was Hopkins' conviction of the fundamental unity of biochemical processes. As we have shown, however, Hopkins' stress on this particular form of unification came relatively late, in the course of the 1920s. Scientifically and rhetorically, "general biochemistry" represents a later stage, if an important one, in Hopkins' construction of dynamic biochemistry. In presenting this construction as a process over time, we hope to have conveyed a more dynamic picture of Hopkins himself.

\section{Conclusion}

We have attempted to show in this paper that Hopkins' construction of dynamic biochemistry as a fundamental and unifying science of life was a dynamic process, in which new directions of research that he (and his immediate colleagues) pursued were, over time, coupled to new emphases in rhetoric. Hopkins continued to make propaganda for dynamic biochemistry in a remarkably persistent way, even long after he had acquired his own department where dynamic biochemistry flourished. Our interpretation of this persistence is that discipline building in the institutional sense may have been less central to Hopkins' endeavours than has been thought. We shall examine this issue further in our second paper, where we consider the images of Hopkins that were constructed by others in his circle, and how these images have informed historians. Here we conclude that any rounded view of Hopkins will need to do justice to his tireless advocacy of distinctive forms of research in the borderland between chemistry and biology, aimed at elucidating the chemical dynamics of biological processes.

\footnotetext{
${ }^{88}$ Hopkins, op. cit., note 37 above, p. 36.

89 Hopkins may also have intended to encourage other members of the audience engaged in biochemical research to strive for institutional autonomy. Many investigators whom Hopkins would
}

have regarded as biochemists, regardless of their institutional affiliations, attended congresses of physiology. The First International Congress of Biochemistry took place in 1949 (in Cambridge). 